\title{
The Latest Developments of Forensic Science Reform in China
}

\author{
Jiang $\mathrm{Na}^{1 *}$ and Wang Yue ${ }^{2}$ \\ ${ }^{1}$ Law Professor, Beijing Normal university, China \\ ${ }^{2}$ LLM Candidate from College for Criminal Law Science, Beijing Normal University, China
}

Submission: January 23, 2019; Published: February 04, 2019

*Corresponding author: Jiang Na, Law Professor, Beijing Normal University, Deputy General-Secretary of the International Association of Penal Law (AIDP) China Branch, China

\section{Introduction}

Over the past 3 decades, numerous miscarriages of justice have occurred in China due to the insufficient or improper use of forensic evidence. Recently, some of these cases have finally been corrected through the proper use of forensic techniques such as DNA testing. This paper will examine responsive forensic reforms in China based on case studies in order to explore into the developing trend of such reforms in near future.

\section{Case Studies}

The judicial rectification of wrongful convictions in the ZHANG Gaoping and ZHANG Hui case has been a good example of promoting forensic reforms in China. For example, in March 2013, ZHANG Gaoping and ZHANG Hui were exonerated for the rape and murder of a 17-year-old girl after DNA evidence was used to link the crime to another man. The two men spent ten years in jail after confessing to murder and rape under torture from police and their fellow inmates. The men were convicted even though DNA was found under the fingernails of the victim that did not belong to either man. The DNA evidence was ignored until 2012, when police finally confirmed that the DNA was that of Gou Haifeng, a man who had confessed to the murder of another girl and was executed in 2005. In response to this new evidence, the ZHANGS were finally exonerated.

The case of the ZHANG Gaping and ZHANG Hui highlights the injustice that can result when forensic evidence is ignored in favor of wrongful confessions extorted under police torture. The ZHANGs' exonerations were made possible by forensic evidence reforms in China that are intended to protect forensic experts who provide critical evidence in court from official retribution and to prevent illegally obtained evidence from being used to convict the innocent. Concerning the protection of witnesses, the Decision of the Standing Committee of the National People's Congress on Administration of Forensic Identification (2005 Decision) attempted to increase the independence of forensic experts, mainly by abolishing court forensic agencies, developing social agencies and restricting investigative bodies. But more protection and independence were needed for forensic experts to prevent biased authorities from interfering with the reliability of the forensic evidence they provide. Furthermore, the new Criminal Procedure Law (CPL), effective 2013, excludes illegally obtained evidence and protects expert witnesses who testify in court, albeit for the general protection of human rights, rather than for the protection of forensic evidence. China's reformers aim to shake up the justice system and improve human rights by reforming how Chinese courts use forensic evidence.

For much of China's history, China's justice system has focused more on obtaining convictions for the authorities' convenience or on giving severe and swift punishments for suspected crimes to calm down popular indignation than on determining the truth of the allegations against the accused. Also, police and prosecutors have traditionally relied more on confessions of guilt to obtain convictions than on physical evidence, to obtain a high conviction rate or a satisfactory number of solved cases. Generally, Chinese police and prosecutors need a good record of obtaining convictions in order to obtain promotions. This leads to a vicious circle of the game on rates or numbers, such that '[n]umbers make leaders' and 'leaders make numbers' [1]. The "game of rates and numbers" has a particularly pernicious effect on the Chinese justice system because justice officials can burnish their records by obtaining wrongful convictions as well as by creating false reports.

One consequence of China's traditional legal culture is that China's organizations for gathering and evaluating forensic evidence are generally underdeveloped, and function primarily for the benefit of the State, rather than for the accused. Although China has undertaken several waves of forensic science reform, it is doubtful that the current 'uniform' system of forensic identification will be able to ensure the objectivity, fairness and reliability of forensic evidence.

\section{Achievements and Progress}

In order to build support with the police and prosecutors for an overhaul of China's system of forensic investigation, the current centerpiece of the government's reform strategy is to 
create a series of independent scientific institutes that provide forensic analyses for police, prosecutors and defense lawyers alike. The reformists face a tough task, however, in convincing their colleagues that forensic experts should not be affiliated with the authorities who collect evidence to be analyzed, the necessity of abolishing police forensic sectors, like crime scene investigation units, and of the best way to fix China's failing system of forensic science. China's forensic reforms have so far retained police forensic agencies without greater independence but under police control, while developing social sectors, and have achieved some progress on building the capacity of forensic agencies, particularly those inside police.

Over the past 8 years, the Ministry of Public Security (MPS) has implemented a range of effective measures to further the standardization and modernization of forensic appraisal, as well as to build the capacity of police forensic agencies where investigators do not work well. In such police agencies, forensic experts often conduct judicial identification to provide courts with reliable evidence, and the reforms help these experts produce more accurate forensic appraisals in court, even though not all judges subsequently admit them as forensic evidence. By increasing investment, improving certification and accreditation systems, and introducing new "key institutions", China has expanded the number of forensic experts to form a nationwide net of forensic investigation, leading to greater efficiency of forensic identification and better-quality appraisal results.

There has also been significant progress on infrastructure and equipment construction, with huge investments from the Party committees and governments at all levels. So far, 4 national key judicial authentication institutions, with top 4 ranking of experts and resources, 9 core judicial authentication institutions funded by and affiliated to the police system and 60 key judicial identification laboratories researching areas have been established. China has set up 258 DNA laboratories with overall advanced functions, equipped with 558 DNA sequencing instruments and 94 automatic workstations. These laboratories can analyze 1.2 million samples every year (CNTV, 24-01-2011) Moreover, the government has invested hundreds of billions of RMB in forensic equipment in urban areas, like those involving the Shanghai building for criminal technology, at the international first-class scale and level. In 2009 alone, the central and local authorities transferred total payments of 19.8 billion renminbi (RMB) to the local police (ca. U.S.\$ 2.8 billion, half of which came from the central government), which was earmarked for upgrading the technical equipment of forensic agencies inside the police [2].

Furthermore, the MPS has implemented a national accreditation system for forensic laboratories and identification agencies. This system promotes the transformation and improvement of forensic institutions at all levels of government according to uniform standards. In the tests of forensic proficiency organized by the Ministry of Justice (MOJ), the comprehensive results of the accreditation bodies in all provinces are increasing. For example, in 2011, 97\% of all projects passed the Ministry's examinations [3]. The number of projects where forensic bodies in Zhejiang province that have been deemed to be 'satisfactory' is about $81 \%$, compared to only $51 \%$ of national projects that are deemed "satisfactory" [4].

Another progress indicator is the implementation of a regulatory responsibility for judicial administrative bodies at all levels of government to examine and supervise all forensic bodies, in order to ensure the standardized development of forensic industry. In practice, China has organized annual inspections of accreditation bodies, deployed special examinations on forensic clinical identification and strictly dealt with any identified problems. Responding to the sharp increase of forensic complaints, the MOJ's Approaches to Handling Complaints in Forensic Practice has been conscientiously implemented to regulate complaints and strengthen the supervision of forensic identification. This regulation has been successful in reducing the number of complaints. The system was introduced on 1 June 2010 and has contributed to an obvious drop in the number of complaints, e.g., in Zhejiang Province, from 61 in 2009 to 18 in 2011 among the total of 64,972 cases on the increase annually [5]. This reduction in the number of complaints suggests that the recent progress and achievements of forensic agencies have enabled them to handle more forensic work and improve the good quality of forensic evidence.

\section{Flawed Reform at the Core}

Unfortunately, the remaining problems cannot be solved only by technical, financial or administrative reforms. China's system of forensic investigation suffers from an institutional flaw in that the police currently have the responsibility for both collecting and evaluating forensic evidence. Although the 2005 Reform, mainly implemented by the 2005 Decision, is intended to restrict forensic sectors affiliated to the police, these sectors still dominate forensic investigation. Police agencies providing expert witnesses appear to be popular with courts. In terms of personnel, experience, funding and administrative ranking, police investigators are more advantageous for courts mainly because they help get convictions. Even after the implementation of the CPL, the dominance of the police agencies remains secure. Given the police agencies' focuses on obtaining a high conviction rate, Chinese courts don't want to use impartial forensic evidence from other agencies until this dominance is eliminated.

The 2005 Reform is flawed to its core. In its long march towards the abolition of forensic sectors inside police and prosecutorial agencies, China has allowed police forensic agencies to retain key forensic functions for investigative purposes, such as the identification of the cause of a victim's deaths or the determination of what weapons were used to cause injuries. The reform fails to ensure that forensic experts are independent of police agencies and still empowers police agency experts to conduct more than $90 \%$ of China's forensic 
investigative tasks in practice. The reforms cannot succeed so long as the police continue to oversee the collection, analysis and interpretation of forensic evidence. Given the potential conflicts of interest between impartial experts and police involving illegally obtained evidence, this institutional flaw constitutes a fundamental injustice at the core of the reforms, leaving much room for wrongful convictions. Furthermore, while the 2005 Reform purports to empower independent forensic experts, courts and police still limit their ability to testify in court. Police agencies may decide to not allow impartial forensic experts to testify against police, given their desire to obtain a conviction, and, even in court, judges often exclude independent forensic testimony on the grounds that lengthy cross-examinations of independent forensic witnesses can impair trial efficiency. Finally, when evidence is uncertain, independent forensic experts are often unwilling to testify in court, while police experts are willing to interpret uncertain evidence in favor of the police, thus leaving the defense at a disadvantage.

Given the great pressure which the increasingly rapid development of forensic science and technology has placed on China's forensic system, China cannot yet perform adequate forensic investigation to ensure that criminal trials are fair. Although the central authorities have been proactive in taking efforts to improve China's capacity for forensic investigation, the on-the-ground effects on forensic reforms in different provinces have been mixed. The exclusive power of law enforcement bodies (such as police, procuratorate and courts) to initiate forensic examination means that there is no guarantee that applications from suspects for conducting a necessary or urgent forensic examination on controversial points will be successful. Given widespread corruption and non-uniform standards in practice, some underregulated forensic agencies have been frequently accused of depriving most applicants of their right to a forensic examination. The imbalance between the authorities' power to initiate identification and the accused's right to apply for it leaves the authorities with the opportunity to abuse their power by not acceding to the accused's request. In some cases, impacted by the above problems, the needs of applicants and forensic experts are inadequately considered and their due process rights are not protected. Even if applicants are granted forensic re-examination, the probability of inconsistent appraisals is still very high. For example, independent psychiatric witnesses almost never agree with police psychiatric witnesses. Under such circumstances, courts often judge the merits based on the administrative ranking of forensic sectors or professional titles of experts, in distinguishing between expert appraisals that seem reliable.

\section{Future Developing Trends}

To improve forensic science in China, more independent institutes must be established that 'could carry out research and do casework free of charge, making the results available to [those on] both sides of a case' [6]. The independence of forensic institutes does not necessarily require the abolishment of all forensic sectors affiliated with the authorities, but rules should be put in place to prevent police or other investigative bodies from employing forensic experts in their own forensic sectors to identify evidence collected by police officers or other public investigators. This restriction indicates the scope of forensic sectors' independence from authorities and the essence of abolishing forensic sectors affiliated to police. Accordingly, more social institutes should be greatly expanded to enable them to undertake most forensic work that police agencies currently perform, e.g., judicial identification of evidence collected by the police or prosecutors, and police agencies should take on the forensic workload in cases investigated by non-police, e.g., social forensic sectors, in order to remedy the failings of China's system of forensic science.

As demonstrated by above progress and challenges, China has invested a lot of money to improve the current situation and has made remarkable achievements, but institutional problems of self-investigation and self-identification by investigative organs persist. These problems are at the core of the flawed 2005 Reform and are mainly based on the tradition of placing too much reliance on biased police investigators in judicial decisionmaking, and of arbitrary prohibitions of police agency experts testifying against authorities, given their conflicts of interests. Although the CPL mandates the exclusion illegally obtained evidence and purports to protect experts who testify in court, there has not been any substantial change of the fundamentally unjust system of police self-investigation and self-identification. In practice, this leads to an artificially high conviction rate and erodes the guarantee of cross-examination that police experts are required to attend for testing the accuracy of evidence. It is therefore necessary for China to launch a new round of forensic reform, intended to open more social forensic agencies for use by criminal suspects. These agencies should be independent from police investigators and should be able to re-examine any evidence collected by the police.

Independent institutes could be developed based on current forensic sectors that are independent of the police, such as those affiliated with universities, research institutions, hospitals, and qualified research sectors with a forensic identification certificate granted by national judicial administrative bodies. The authorities should encourage rather than limit private funding for the development of forensic labs in achieving the goal of establishing independent forensic agencies. Such encouragement would represent a promising break from the traditional practice in which most forensic science activities are decided or managed by police investigators without the participation of suspects. Also, providing independent forensic sectors with a broader mandate is essential to better prevent the use of tainted forensic evidence and the subsequent wrongful convictions that such evidence can cause. At the very least, each independent sector 'needs to be a multidisciplinary group to cover the whole criminal justice system', given the 
high risk of wrongful convictions. Additionally, suspects should be able to initiate forensic examinations as a matter of right, and these examinations should be administered separately from the investigations instigated by authorities. All forensic organizations must develop a new culture whereby they serve justice, rather than the convenience of the authorities, allowing their experts to undertake independent and impartial forensic work.

\section{References}

1. Science, 01-06-2013, pp. 1038

2. Ibid.

3. Legal Daily, 21-04-2012.

4. Ibid.

5. Chinese Journal of Forensic Sciences 2011(2), 93; Legal Daily, ibid; CNTV, 27-04-2012.

6. Science, 01-08-2003, pp. 580.

\section{Your next submission with Juniper Publishers} will reach you the below assets

- Quality Editorial service

- Swift Peer Review

- Reprints availability

- E-prints Service

- Manuscript Podcast for convenient understanding

- Global attainment for your research

- Manuscript accessibility in different formats

( Pdf, E-pub, Full Text, Audio)

- Unceasing customer service

Track the below URL for one-step submission https://juniperpublishers.com/online-submission.php 